\title{
Changes in Marketing Strategies and Performance Outcomes of Turkish Firms in 2008 Global Economic Recession
}

\author{
Fahri Apaydın \\ Yalova University, Turkey \\ Tel: 090-0226-814-9932Ｅ-mail: apaydin@yalova.edu.tr
}

Received: February 10, 2011 Accepted: May 14, 2011 doi:10.5539/ibr.v4n4p104

\begin{abstract}
The role of marketing during the economic recession becomes more significant than usual times. It is necessary to understand how firms should adjust their marketing strategies to handle with recessions. Although recessions have been studied primarily in finance and economics, there is a void in marketing literature about it. Recessions have significant effects on consumer behaviors and substantial impacts on firms, and these affect particular socio-demographic strata and business segments in different ways. The effects of recessions need to be examined both to cope with the ensuing problems and to get ready for prospective recessions. This exploratory research paper examines the changing marketing practices, marketing opportunities, and strategies of Turkish firms that were employed to respond to 2008 global economic crises, which caused recession in many economies. It was observed that adjustments are needed in marketing strategies and activities during economic recessions to benefit from arising opportunities and keep away from arising threats.
\end{abstract}

Keywords: Marketing strategy, Recession, Firm performance

\section{Introduction}

Economic recessions, two successive quarters of negative growth in gross domestic product (GDP) (Tellis and Tellis, 2009), cause extensive changes in the economic conditions which form the macro environment of firms. Economic recessions engender uncertainty and thus loss of trust within the business environment. As a result, they create changes in consumer behaviors, relationship between the firms and their customers, and the structure of competition change to a large extent (Moore, 2001).

This study aims to examine the changes Turkish firms made in the marketing strategies as a response to the global economic recession of 2008, which has affected all the countries in the world. This exploratory study is valuable in this manner. Another factor which increases the importance of this study is that it was done during 2008 global economic recession about which there are not enough researches. Moreover, this study proposes possible strategies that could be applied in prospective economic recessions based on the strategies applied by the firms in this period.

\section{Literature Review}

Economic recessions are times of adversity for firms in which financial institutions stress, industrial goods' sales go down, consumer demand decrease, retailers go bankrupt, and etc. In these 'hard times', organizations try to survive rather than grow using the competitive advantages they have acquired by then (Hunt, 2009; Duncan, 1972). Each recession affects firms in different ways, and no recession is quite the same as the previous one. Some industries might be affected positively while others are affected vice verse for the reason that customers change their spending habits during these periods as their income level usually detoriate (Shama, 1993; Sinkula, 1994; Dess and Beard, 1984). Sales depend on not only the type of products being sold but also the type of customer doing the buying. "The occasion of a recession may call for a particularly aggressive and well-crafted marketing program to counter the pessimism attributed to the hard times" (Piercy et. al., 2010). Thus, it could be inferred that while economic recessions pose threats for some industries, they may create opportunities for some other industries.

Sham (1978) suggests that "during economic recession, process of decreasing demand for raw materials, products, and services, including labor is observed". A lot of labor is laid off, wages are not paid regularly to the employee, and the rate of hiring new employees go down, all of which cusae a slow down in the economic activities. In effect, as economy shrinks demand for almost any kind of goods declines. In such an environment, strategies to encourage demand are needed to be applied, which is really a challenging task as consumers become reluctant to spend and take precautions related with their personal budget.

Managers often respond to recessions by severely decreasing orders for raw materials and supplies, because they fear that falling sales figures might result in extra inventory cost and financial losses. However, taking such severe measures can deepen a recession even more and create a vicious circle (Werner, 1991). Some researchers consider 
taking such measures as acting shortsightedly. Most importantly in these periods uncertainty is prevailing and it becomes even more difficult for managers to make decisions related with every aspect of the organization. Managers due to uncertainty can not make planning which is the main function of management. So they are more likely to make precipitous decions which might harm the position of the organization within the market place. Usually, higher-paid workers are dismissed to cut costs. However, in such cases there may be a loss in the organization's institutional memory as it relates to customer knowledge and skills in relationship management. Inexperienced employees who understand neither their firm's service capabilities nor their customer's needs deal with customers are hired, so they may fail to develop strong relationships with customers (Latham and Braun, 2009). Thus, this will result in losses of customers and sales. In such times understanding the customer needs become even more important. Losing the employees who already know a lot about the cutomers might hinder to developing new strategies to change the threat into opportunity. For example, they may lay off skilled and knowledgeable employees, which is in fact losing valuable resources. After the economy starts to grow it might not be easy to replace such employees (Chandler, et. al., 2000; Kangasharju and Pekkala, 2000). This also creates a loss of trust towards the organization among the employees and as a result exacerbates the situation.

During these periods, managers usually change marketing strategies as it is the easiest and fastest way of getting results. As sales and profits go down, a common first reaction of firms to it is to engage in price promotions to recover lost sales volume. As a result "margins are depressed resulting in attracting new, price-sensitive customers who are inherently disloyal because they can easily be enticed away by the other competitors that offer even more attractive terms" (Lovelock, 1997). A worse result of such approach is that "customers adopt to new price level and they expect such prices to continue at low level even after the recovery from the recession”, which affects firms' revenue negatively in the long run.

In recessions, many firms usually cut back on all expenses they consider unnecessary, and this approach may lead some firms to reduce their advertising expenditures seeing as unnecessary for that time as the demand goes down. As a result, media owners charge less rates for advertising. However, marketing experts advice firms to continue to advertise, since managers can negotiate media deals at dramatically lower rates. But in effect, only financially strong companies usually exploit these opportunities. Firms that are aware of this and have the financial capabilities increase promotions very selectively in advertising media, building value of their brands in the long term (Chou and Chen, 2004; Shama, 1993; Apaydın and Geçti, 2011).

Firms need to reevaluate precisely their entire costs including marketing costs during recession periods. They should do value analysis and cease the activities which do not create value in these times. This requires managers to control costs by "rethinking the wasteful spending habits developed in previous years" (Kotler and Caslione, 2009; Werner, 1991; Chou and Chen, 2004) instead of cutting vital marketing activities such as advertising.

Decreasing profits may lead to panicky efforts to curtail costs, often by laying off employees, decreasing service hours, neglecting maintenance, and eliminating value-added activities some of which might be related with service features. The result is usually "decline in service quality, including such negative elements as extended delays while waiting for service, elimination or downgrading of small "extras" that enhanced the service experience, a deteriorating physical appearance in buildings and equipment, and a lack of reliability in service delivery", which weakens brand equity in the long run (Tellis and Tellis, 2009).

Organization may cut back productive capacity in order to adjust to the reduced levels of demand. Physical assets are usually disposed of at low prices during a recession to decrease the productive capacity. When the economy eventually recovers again, the firm may find itself unable to supply the expanding demand of those customers that have remained loyal, thus may lose competitive advantage and open doors to aggressive competitors (Lovelock, 1997).

Due to the different nature of recessions conflicting recommendations have been made by the economists and researchers. Some theorists suggest that a market orientation approach will help organizations to handle with such times, while others urge managers to carefully resegment markets and focus on innovations (Hunt, 2009; Croft, 2002). Marketing managers should be aware of how different strategies would apply more successfully in such situations, understand the rising competition, and analyze dimensions of competitive advantage.

Companies "that have extended relationships with their customers before economic recessions" are less affected from them due to strong relationship. This indicates the importance of relationship marketing. Developing strong relationships during normal market conditions (recessions are considered as unsual market conditions) is a proactive approach to get ready for possible recessions, which happens randomely and frequently in complex globalized markets. During economic recessions the relationship with the suppliers becomes more important like the relationship with customers. Thus, developing strong relationships with supplies can make the firms less susceptive to economic recessions (Mattsson, 2009; Lamming, 2000).

As consumer behaviors go under big changes during recession times, some firms resegment the market. As purchasing behaviors of consumers revolve in such times, "detailed segmentation analysis" can help to uncover distinctive emerging needs and wants (Lovelock, 1997). Most consumers become price sensitive during these 
periods. Some firms may consider cutting prices to attract such consumers. However, doing so might damage the image of the firms and harm the income of the firm after the economic recessions. The reason for that is explained by some researches, claiming that "consumers continue to behave after the economic recessions in the way they behave during economic recessions". Instead, developing inexpensive services and goods that are tailored to the changing needs of such customers may less damage the profitably or even contribute to it positively.

Some firms try to find ways to add value in a recessionary environment without cutting prices on existing products. During economic recessions some customers are more interested in value of the products. "Supplementary services that enhance the core product could be relatively inexpensive to offer, yet provide a meaningful way to differentiate what might otherwise be a commodity product facing price-based competition” (Lovelock, 1997).

"Recessions are sobering periods for many people, requiring changes in habitual spending and consumption patterns. Many consumers suffer from a drop in income, job uncertainty, or problems associated with seeking a new job. Tough times can deeply affect consumers in subtle and profound ways” (Boress, 1993; Shama, 1993). As a result buying patterns and behaviors of consumers undergo significant changes as discussed above. The success of business in a period of economic recession depends on understanding new environment and chnaing consumer attitudes and needs.

Goodell and Martin (1992) explain changes in the consumers' behaviors during economic recessions are as follows:

1. Consumers will have sharply reduced amounts of disposable income and an emotional reluctance to expend in the face of economic uncertainty.

2. Repair and do-it-yourself activities will increase, as consumers delay or reduce purchases of new or replacement items.

3. A polarity of consumption behavior will start forming between a small, wealthy segment and a broad mass of consumers seeking only basic necessities.

4. Price-value will be emphasized over time convenience.

5. Many middle- and lower-income consumers deferring purchase of expensive durables and continue to use their old equipment or borrow.

6. Total leisure spending decreases.

Nine roles of marketing in a recession might be summarized as follows (Grossberg, 2009; Goodell and Martin, 1992; Allen, 2009; Freiman, 2001; Hollinger, 2009; Levinthal and Nardi, 1993)

1. To devise new strategies and tactics to help sell off swollen inventories so that industry may resume fuller production and rehire the unemployed.

2. To assert more strongly its role within the councils of the firm so that decision-making control, under the duress of economic adversity, is not seized even more by the financial function to the detriment of aggressive marketing.

3. To continue to invest in new product development, advertising, and sales promotion so as to reap the disproportionate rewards which will come when the recession ends.

4. To use the marketing intelligence function even more to understand consumer attitudes and behavior as a foundation for product policies.

5. To continue to recognize the contribution the firm must make to the welfare of the larger society: today's altruism is tomorrow's self-interest.

6. To become even more inventive in creating customer benefits and making end runs around consumer resistances.

7. To recognize, and to educate others in the firm to recognize, that the tasks of marketing are becoming more crucial rather than less crucial during a recession.

8. To develop integrated marketing plans.

9. To apply the marketing concept rather than pay lip service to it.

Some researchers examining the previous economic recessions listed possible adjustments a firm may make in their marketing activities and strategies as a response to economic recessions and they are as follows (Goodell and Martin, 1992; Shama, 1978; Tellis and Tellis, 2009; Zehir, 2005; Baker, 2009):

\section{Product}

1. Narrow product line.

2. Offer cheaper, more functional products.

3. Cut top of product line.

4. Use less raw materials in production.

5. Offer quantity discounts.

Price
14. Motivate sales force to sell more.

\section{Place}

15. Increase distribution outlets.

16. Motivate middlemen to buy more of product and push it.

17. Offer products directly to consumers

\section{Consumer}


6. Lower prices whenever possible.

7. Change price differential to increase total demand.

8. Offer price discounts.

9. Loosen credit.

10. Centralize price decisions.

\section{Promotion}

11. Remarketing through promotion.

12. Increase promotion to stimulate demand.

13. Cultivate every potential account and territory.

Based on the literature review and observations following research questions are examined in the research part of this study:

- What kind of changes do firms make in their products to decrease the negative effects of economic recession?

- What kind of changes do firms make in their promotion activities to decrease the negative effects of economic recession?

- What kind of changes do firms make in their production facilities to decrease the negative effects of economic recession?

- What kind of changes do firms make in market segmentation to decrease the negative effects of economic recession?

- What kind of changes do firms make in research and development to decrease the negative effects of economic recession?

- How do firms can turn economic recession into opportunity?

- What kind of adjustments in marketing activities and strategies yield better performance results?

\section{Methodology and Results}

The space of this exploratory study consists of the firms which are members of Istanbul Chamber of Commerce and Istanbul Chamber of Industry. 200 Firms which were small and medium sized were selected from different industries to make generalizations. The survey was done with face to face interviews with the marketing managers of firms using structured questionnaire developed in the form of Likert-like scale during May-June 2009 in which the effects of the global economic recession were being felt deeply. The data were analyzed using SPSS program.

Multi-item scales are used to operationalize all the constructs in the survey. The measurements adopt the 5-point Likert scales with the end points of 'strongly disagree' and 'strongly agree'. Marketing activities are so broad that it is not possible to research all of them in one research, so decisions of product, promotion, production, segmentation and research and development are examined in this study. The statements about the marketing activities are shown in Tables IV, V, VI, VII, and VIII. Exploratory factor analyses about the marketing activities were carried out and the results are shown in Table I. In the table factors and items loaded to factors and factor loads can be seen. Also the variances the factors explained about the marketing activities can be seen in Table I. Firm performance was measured with revenue, sales, and market share. Another factor analyses were carried out for the firm performance. The results are shown in Table II. In the table factors, their loadings and the variance they explain can be seen. Items having an Eigenvalue of 1 were selected. Verimax rotation with Kaiser Normalization was applied to make explaining factors clearer and items were aggregated to form the constructs. Then correlation analysis was done and the correlations, means and the standard deviations for all the constructs are indicated in Table III.

The statements about the changes firms made with their products are seen in Table IV. As it is seen in the table, while most of the firms enriched their products and made innovation, standardization and simplifying the products are not applied by most of the firms.

Table $\mathrm{V}$ indicates that most firms empowered sales people and increased public relationship during economic recession. This was advised by many researchers as relationships between customers become more important then ever during recession periods. However, few of the firms made changes with advertising although they were expected to make significant changes with the advertising.

Table VI shows that most of the firms made innovation in their production facilities and methods. During recession times prices go down, so this could create opportunity for the firms to renovate their aging production facilities, thus their production methods. On the other hand, they did not increase their production capacity, which is in line with the literature.

In the literature review part, it was mentioned that it was necessary for firms to reach different segments in the market because of the changes in consumer behaviors and patterns as well as income of the consumers. Table VII 
supports this finding, in that most of the firms are observed to enter new market segments. However, it is interesting to see that most of them preferred to enter upscale segments.

In the literature review, it was mentioned that so many factors about the marketing environment change due to economic recession, which requires firms to understand the new marketing environment. In the new environment, consumers' expectations and preferences and competition evolve. Therefore, firms need to capture the new marketing conditions. To do so they need to do more research to be able to gain from emerging opportunities. Table VIII supports the literature, in that it is seen that many firms increase their research activities and spendings.

T-tests were carried out to test which of the changes in the marketing activities done by firms provided better results in various performance indicators. I took any means of performance indicators above 3 as positive performance result and any below 3 as negative performance result and created two groups and then tested the significance of the differences between means of groups in terms of various marketing activities. All significances are two tailed.

Table IX shows the results of t-test of overall performance results to see the significance among the means of the changes firms made in various marketing activities. 106 fell into the group whose means are over 3 and 74 firms fell into the group whose means are below 3 . There is a significant difference (alpha level is below .05) between means of the firms which had positive overall performance result and negative performance result in terms of product enrichment, development and innovation (F1). The firms which developed, enriched, and made innovations with their products more had better overall performance results, as their means are higher than the others. Firms which empowered their sales people more (F3) and increased public relation activities performed better (alpha level is below .05), which is in line with literature. Firms which renovated their production facilities and methods (F6) performed better (alpha level is below .05). Firms that entered upscale consumer markets (F7) had better performance (alpha level is below .05). Another significant finding is that firms which increased their research and development activities (F9) performed better (alpha level is below .05). On the other hand, there is no significant difference (alpha levels are above .05) between means of the firms which had positive overall performance result and negative performance result in terms of product standardization (F2), making changes with advertising (F5), and entering downscale consumer segments (F8).

Table $\mathrm{X}$ shows the results of t-test of revenue performance results to see the significance among the means of the changes firms made in various marketing activities. Out of 200 firms 118 firms had negative and 73 firms had positive performance in terms of revenue. There is a significant difference (alpha level is below .05) between means of the firms which had positive revenue performance result and negative revenue performance result in terms of product enrichment, development and innovation (F1). While the firms which developed, enriched, and innovated their products had higher revenue, firms which standardized and simplified their products (F2) had low revenue (alpha level is below .05). Firms that entered upscale consumer markets (F7) had higher revenues than the ones which entered downscale consumer market (F8) (alpha level is below .05). On the other hand, there is no significant difference (alpha levels are above .05) between means of the firms which had positive revenue performance result and negative revenue performance result in terms of promotion activities (F3, F4, F5), innovating production facilities and methods (F6), and increasing research and development activities (F9) (alpha level is above .05).

Table XI shows the results of t-test of sales performance results to see the significance among the means of the changes firms made in various marketing activities. Out of 200 firms 80 firms had negative and 102 firms had positive performance in terms of sales. There is a significant difference (alpha level is below .05) between means of the firms which had positive sales performance result and negative sales performance result in terms of product standardization and simplification (F2). Firms which standardized and simplified their products increased their sales more. This finding supports the literature, in that consumers' income level decrease during recession so they prefer cheaper products. Firms changing production facilities (F6) also face the same result, which is decrease in the sales. While firms which enter upscale consumer segments (F7) sell less of their products, firms entering downscale (F8) consumer segments sell more. No significant difference is observed between these two groups of firms (firms have positive sales performance and firms having negative sales performance) in terms of other marketing activities.

Table XII shows the results of t-test of market share performance results to see the significance among the means of the changes firms made in various marketing activities. Out of 200 firms 95 firms had negative and 56 firms had positive performance in terms of market share. There is a significant difference (alpha level is below .05) between means of the firms which had positive market share performance result and negative market share performance result in terms of product enrichment and product renovation (F1). It is obvious from the table that enriching and renovating their products did not help many firms to increase their market share. Firms changing product facilities and methods (F6) also face the same result. There is a significant difference (alpha level is below .05) between means of the firms which had positive market share performance result and negative market share performance result in terms of changing production facilities and methods. No significant difference is observed between these two groups of firms (firms have positive sales performance and firms having negative sales performance) in terms of other marketing activities. 


\section{Discussion}

According to the results of the study firms which enrich their products, make innovation, and increase the features of the products perform better than the ones which make standardization and decrease the features of the products. For this reason, instead of focusing on the costs of products and taking precautions to decrease the costs of products, managers should endeavor to understand the changes in the behaviors of customers and develop their products. They should also make innovation with their production facilities and methods. Economic recessions usually provide opportunities for companies to be creative and develop new products (Caudillo-Fuentes and $\mathrm{Li}$, 2010). In this manner, it is significant to be close to customers and have strong relationships with them.

It was mentioned that loss of trust was experienced within the business environment and the structure of competition changed and the competition get tougher within the marketing environment. Especially it was observed that financially stronger firms were spending effort to capture the customers of weaker ones. Companies with strong financial resources can use their financial power to their advantage in markets where private or corporate customers have sharply reduced access to credit. Therefore, firms should build strong relationships with their customers and prevent loss of trust and to do so firms should change the way of communicating with their customers and send relevant messages to the new environment. Moreover, new business models which are more relevant to changing or emerging customer needs should be developed and implemented. In the literature, it was found in some researches that decreasing the promotional activities would be a fatally strategic mistake for firms. This finding was supported by the results of this study. Companies need to adjust their communications as the importance of certain buying criteria changes during recessions (Simon et. al., 2009). Consumers develop some kind of barriers to buying, so marketers should understand these barriers and choose the marketing vehicles and messages that will overcome these barriers. The suggestion made that "while high market share companies should spend money on closing the sale, a low market share company first needs to increase awareness to higher levels, and mass advertising works best" by Kotler and Caslione, 2009 is supported with this stduy. Empowering salespersons increases their contribution to finding creative solutions to the problems of customers. So during recession time organizations should use relevant tools to empower the salespeople. Another interesting finding was that public relations gave desired results in terms of protecting the image of the firms.

During period of an economic recession, some of the most significant decisions are made about market segmentation. In the literature review part, it was mentioned market should be "resegmented" in economic recession period. Consumers' value perception undergoes an important change and core benefits of products are valued more, which is also supported by the results of this research. Thus, firms could analyze their market segments and enter more profitable ones. Furthermore, as economic recession impacts various segments differently, it is posited that firms might consider entering the emerging markets.

Firms should adjust their marketing activities, which might involve increasing resources to take advantage of various types of opportunities that arise in recessions. Acquiring new resources when the costs for acquisition is low or developing new products in anticipation of a coming upturn following the recession might help the organizations to keep their positions in the market place (Mattsson, 2009). Recession is a time of opportunity for the firms which have strong financial resources and want to pursue growth. As competitors providing poorer service, it becomes easier to attract their customers during recessions than in normal times. To cut down costs competitors may have laid off some talented staff, so adding new talented employees might increase firms' innovation capacity and develop better relationships with the customers. Another significant point firms should take into consideration is that new customers appear, so firms which will spot product and service gaps that they can close will increase their performances.

This research also reveals that to capture the change within the consumer behaviors, firms should increase research and development activities. This will provide them to make innovation with their products and production facilities in the way consumers' preferences alter.

Though insightful, this research has several limitations. The research design relies on small and medium sized firms, whereas big firms are not included in the survey. Examining their marketing activities would provide deeper understanding of the changes in marketing activities of bigger firms in an economic recession. Second, sample size was small due to time and financial constraints and, as a consequence, the generalizability of the findings is limited. Third, it is obvious that economic recessions affect various industries differently. However, the sample of this research consists of firms from various industries, which weakens the findings. However, as this study is exploratory, it might be a sample for future studies and does not diminish the contributions of the study.

This research can be extended in several important ways. Some other marketing activities such as pricing strategies of firms during economic recessions should be investigated. Some of the more interesting topics for future research are ones how firms could increase the effectiveness. Another research area might be the difference between strategies applied by small firms and big firms. Respondents have answered the questions regarding the performance of the firms while economic recession was still being felt. So a potential research area focuses on performance of the firms after the recovery from economic recessions. 


\section{References}

Apaydın, F., Geçti, F. (2011). Analyzing the changes in marketing activities of Turkish enterprises in the period of economic crisis. Proc. of the Annual International Conference on Enterprise Marketing and Globalization (EMG 2011), Malaysia, 30-35.

Allen, P. (2009). Marketing tools for survival. Chemistry Industry, January.

Baker, M.J. (2009). Marketing in adversity. Journal of Consumer Behavior, 8(2), 97-103.

Boress, A.S. (1993). Marketing in troubled waters. Journal of Accountancy, March, 38-44.

Caudillo-Fuentes, L. and Li, Y. (2010). Revenue management during times of recession. Journal of Revenue and Price Management, 9: 185-188, doi:10.1057/rpm.2009.32, http://dx.doi.org/10.1057/rpm.2009.32.

Chandler, G.N., Keller, C., and Lyon, D.W. (2000). Unraveling the determinants of an innovation-supportive organizational culture. Entrepreneurship Theory and Practice, 25(3), 59-76.

Chou, T.J., Chen, F.T. (2004). Retail pricing strategies in recession economies: The case of Taiwan. Journal of International Marketing, $\quad$ 12(1): $\quad$ 82-102, $\quad$ doi:10.1509/jimk.12.1.82.25650, http://dx.doi.org/10.1509/jimk.12.1.82.25650.

Croft, A. (2002). Surviving the recession by practicing the four "Ps" of agency prosperity: positioning, promotion, productivity and profitability. Public Relations Quarterly, Summer, 25-28.

Dess, G. and Beard, D. (1984). Dimensions of organizational task environment. Administrative Science Quarterly, 29, 51-73, doi:10.2307/2393080, http://dx.doi.org/10.2307/2393080.

Duncan, R. (1972). Characteristics of organizational environments and perceived uncertainty. Administrative Science Quarterly, 2, 409-443.

Freiman, D.J. (2001). Smart marketing in a time of economic crisis. Advanced Management Journal, 12, 21-34.

Goodell, P.W., Martin, C.L. (1992). Marketing strategies for recession survival. Journal of Business and Industrial Marketing, 7(4), 5-17, doi:10.1108/08858629210037236, http://dx.doi.org/10.1108/08858629210037236.

Grossberg, K.A. (2009). Marketing in the Great Recession: an executive guide. Strategic Leadership, 37(3), 4-8, doi:10.1108/10878570910954583, http://dx.doi.org/10.1108/10878570910954583.

Hollinger, P. (2009). Corporate ‘I don’t know’ factor rises. Financial Times, June 4, 9.

Hunt, S.D. (2009). Competitive advantage strategies in times of Adversity. Journal of Customer Behavior, 8(2), 137-151, doi:10.1362/147539209X459769, http://dx.doi.org/10.1362/147539209X459769.

Kangasharju, A and Pekkale, S. (2000). The effects of aggregate fluctuations on regional economic disparities in Finland. Pel. Eco. Res. Inst. Rep., 2-27.

Kotler, P. and Caslione, J.A. (2009). How marketers can respond to recession and turbulence? Journal of Customer Behavior, 8(2), 187-191, doi:10.1362/147539209X45980, http://dx.doi.org/10.1362/147539209X45980.

Lamming, R. (2000). Japanese supply chain relationships in recession. Long Range Planning, 33, 757-778, doi:10.1016/S0024-6301(00)00086-8, http://dx.doi.org/10.1016/S0024-6301(00)00086-8.

Latham, S.F. and Braun, M.R. (2009). Assessing the relationship between financial slack and company performance during an economic recession: An empirical study. International Journal of Management, 26(1), 33-39.

Levinthal, D.A. and Nardi, T.G. (1993). The myopia of learning. Strategic Management Journal, 14(Winter), 95-112, doi:10.1002/smj.4250141009, http://dx.doi.org/10.1002/smj.4250141009.

Lovelock, C.H. (1997). Fear of a recession: The best way to deal with it is to prepare for it. Marketing Management, Fall, 14-16.

Mattsson, L.G. (2009). Market orientation and resource adjustments during economic recession - a business network perspective. Journal of Customer Behavior, 8(2), 153-162, doi:10.1362/147539209X459778, http://dx.doi.org/10.1362/147539209X459778.

Moore, M. (2001). Turkey’s working class hit hardest by crisis. International Business, 367, 16-22.

Piercy, N.F., Cravens, D.W., and Lane, N. (2010). Marketing out of the recession: Recovery is coming, but things will never be the same again. Marketing Review, 10(1), 3-23, doi:10.1362/146934710X488915, http://dx.doi.org/10.1362/146934710X488915.

Shama, A. (1978). Management \& consumers in an era of stagflation. Journal of Marketing, July, 43-54, doi:10.2307/1250533, http://dx.doi.org/10.2307/1250533.

Shama, A. (1993). Marketing strategies during recession: A comparison of small and large firms. Journal of Small Business Management, July, 62-72.

Simon, H. and Partners (2009). The crisis and customer behaviour: Eight quick solutions. Journal of Customer Behavior, 8(2), 177-186, doi:10.1362/147539209X459796, http://dx.doi.org/10.1362/147539209X459796. 
Sinkula, J.M. (1994). Market information processing and organizational learning. Journal of Marketing, 58(January), 35-45, doi:10.2307/1252249, http://dx.doi.org/10.2307/1252249.

Tellis, G.J. and Tellis, K. (2009). Research on advertising in a recession: A critical review and synthesis. Journal of Advertisement $\quad$ Review, 49(3), 304-327, doi:10.2501/S0021849909090400, http://dx.doi.org/10.2501/S0021849909090400.

Werner, L.R. (1991). Marketing strategies for the recession. Management Review, August, 30-31.

Zehir, C. (2005). The activation level of crises and the change of strategic targets of enterprises in Turkey during the depression era. Journal of American Academy of Business, 5(2), 293-9.

Table I. Results of exploratory factor analysis of marketing activities

\begin{tabular}{|c|c|c|c|c|c|c|c|}
\hline $\begin{array}{l}\text { Marketing } \\
\text { activities }\end{array}$ & \begin{tabular}{|l|} 
Factors and \\
Statements \\
\end{tabular} & \multicolumn{4}{|c|}{ Factor Loads } & $\begin{array}{l}\text { Variance } \\
\text { Explained \% } \\
\end{array}$ & \begin{tabular}{|l|} 
Total Variance \\
Explained \% \\
\end{tabular} \\
\hline \multirow{9}{*}{ Product } & \multirow{6}{*}{ 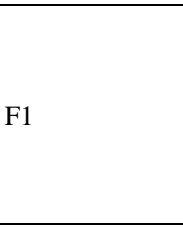 } & 1 & 0,79 & & & \multirow{6}{*}{35} & \multirow{9}{*}{52,64} \\
\hline & & 2 & 0,78 & & & & \\
\hline & & 3 & 0,75 & & & & \\
\hline & & 4 & 0,72 & & & & \\
\hline & & 5 & 0,62 & & & & \\
\hline & & 6 & 0,62 & & & & \\
\hline & \multirow{3}{*}{ F2 } & 7 & & 0,73 & & \multirow{3}{*}{17,64} & \\
\hline & & 8 & & 0,68 & & & \\
\hline & & 9 & & 0,67 & & & \\
\hline \multirow{6}{*}{ Promotion } & \multirow{2}{*}{ F3 } & 1 & 0,81 & & & \multirow{2}{*}{16,59} & \multirow{6}{*}{60,62} \\
\hline & & 2 & 0,63 & & & & \\
\hline & \multirow{2}{*}{ F4 } & 3 & & 0,82 & & \multirow{2}{*}{18,13} & \\
\hline & & 4 & & 0,66 & & & \\
\hline & \multirow{2}{*}{ F5 } & 5 & & & 0,85 & \multirow{2}{*}{25,89} & \\
\hline & & 6 & & & 0,79 & & \\
\hline \multirow{3}{*}{ Production } & \multirow{3}{*}{ F6 } & 1 & 0,80 & & & \multirow{3}{*}{48,49} & \multirow{3}{*}{48,49} \\
\hline & & 2 & 0,67 & & & & \\
\hline & & 3 & 0,59 & & & & \\
\hline \multirow{5}{*}{ Segmentation } & \multirow{3}{*}{ F7 } & 1 & 0,74 & & & \multirow{3}{*}{30,26} & \multirow{5}{*}{58,2} \\
\hline & & 2 & 0,68 & & & & \\
\hline & & 3 & 0,60 & & & & \\
\hline & \multirow{2}{*}{ F8 } & 4 & & 0,77 & & \multirow{2}{*}{27,93} & \\
\hline & & 5 & & 0,72 & & & \\
\hline \multirow{4}{*}{$\mathrm{R} \& \mathrm{D}$} & \multirow{4}{*}{ F9 } & 1 & 0,75 & & & \multirow{4}{*}{42,06} & \multirow{4}{*}{42,06} \\
\hline & & 2 & 0,69 & & & & \\
\hline & & 3 & 0,67 & & & & \\
\hline & & 4 & 0,41 & & & & \\
\hline
\end{tabular}

Table II. Results of exploratory factor analysis of firm performance

\begin{tabular}{|c|c|c|c|c|c|}
\hline \multirow{4}{*}{$\begin{array}{c}\text { Performance dimensions } \\
\text { Overall performance }\end{array}$} & \multicolumn{3}{|c|}{ Factor loadings } & \multirow{3}{*}{\begin{tabular}{|c|} 
Variance explained \% \\
14,2 \\
\end{tabular}} & \multirow{2}{*}{\begin{tabular}{|l} 
Total variance explained \% \\
\end{tabular}} \\
\hline & 0,84 & & & & \\
\hline & 0,73 & & & & \multirow{10}{*}{67,44} \\
\hline & 0,46 & & & & \\
\hline \multirow{3}{*}{ Revenue } & 0,82 & & & \multirow{3}{*}{18,61} & \\
\hline & 0,76 & & & & \\
\hline & 0,73 & & & & \\
\hline \multirow{3}{*}{ Sales } & & 0,84 & & \multirow{3}{*}{18,18} & \\
\hline & & 0,74 & & & \\
\hline & & 0,61 & & & \\
\hline \multirow{2}{*}{ Market share } & & & 0,83 & \multirow{2}{*}{16,44} & \\
\hline & & & 0,82 & & \\
\hline
\end{tabular}


Table III. Descriptive statistics and correlations

\begin{tabular}{|l|l|l|l|l|l|l|l|l|l|l|l|l|l|l|}
\hline Factors & Mean & Std. Dev & F1 & F2 & F3 & F4 & F5 & F6 & F7 & F8 & F9 & $\begin{array}{l}\text { O. } \\
\text { per }\end{array}$ & Rev. & Sales \\
\hline F1 & 3,75 & 0,82 & 1,00 & & & & & & & & & & \\
\hline F2 & 3,15 & 0,93 & $-0,04$ & 1,00 & & & & & & & & & \\
\hline F3 & 3,50 & 0,92 &, $34^{* *}$ & $-0,07$ & 1,00 & & & & & & & & & \\
\hline F4 & 3,44 & 0,82 &, $22^{* *}$ & $-0,05$ & 0,13 & 1,00 & & & & & & & & \\
\hline F5 & 2,83 & 0,99 & 0,14 &, $18^{* *}$ & 0,06 &, $44^{* *}$ & 1,00 & & & & & & & \\
\hline F6 & 3,29 & 0,84 &, $52^{* *}$ & 0,10 &, $45^{* *}$ & 0,13 & 0,12 & 1,00 & & & & & & \\
\hline F7 & 3,57 & 0,82 &, $56^{* *}$ & $-0,06$ &, $35^{* *}$ &, $25^{* *}$ & 0,01 &, $34^{* *}$ & 1,00 & & & & & \\
\hline F8 & 3,29 & 0,96 &, $19^{* *}$ &, $33^{* *}$ & 0,03 & $-0,01$ & 0,05 &, $14^{*}$ &, $14^{*}$ & 1,00 & & & & \\
\hline F9 & 3,51 & 0,71 &, $35^{* *}$ & 0,01 &, $32^{* *}$ &, $36^{* *}$ &, $18^{*}$ &, $23^{* *}$ &, $42^{* *}$ &, $15^{*}$ & 1,00 & & & \\
\hline Overall per. & 3,16 & 1,00 &, $34^{* *}$ & 0,06 &, $40^{* *}$ &, $19^{* *}$ & 0,13 &, $47^{* *}$ &, $43^{* *}$ & 0,03 &, $20^{* *}$ & 1,00 & & \\
\hline Revenue & 3,44 & 0,99 & $-0,09$ & 0,02 & $-0,03$ & 0,04 & $-0,13$ &,$- 14^{*}$ & $-0,04$ & 0,12 & $-0,04$ & $-0,07$ & 1,00 & \\
\hline Sales & 3,15 & 1,11 &,$- 14^{*}$ &, $16^{*}$ & $-0,13$ & 0,06 & $-0,11$ &,$- 21^{* *}$ &,$- 14^{*}$ &, $24^{* *}$ & $-0,02$ & $*$ &, $39^{* *}$ & 1,00 \\
\hline Mark. share & 2,80 & 1,05 &,$- 22^{* *}$ &, $15^{*}$ & $-0,06$ & $-0,07$ & $-0,02$ &,$- 21^{* *}$ & $-0,08$ & 0,12 & $-0,06$ &,$- 14^{*}$ &, $36^{* *}$ &, $44^{* *}$ \\
\hline
\end{tabular}

** Correlation is significant at the 0.01 level (2-tailed).

* Correlation is significant at the 0.05 level (2-tailed).

Table IV. Changes related to product

\begin{tabular}{|c|c|c|c|c|c|c|c|c|c|c|c|}
\hline \multirow[t]{2}{*}{ Statements } & \multicolumn{2}{|c|}{ 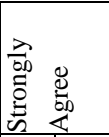 } & \multicolumn{2}{|c|}{ 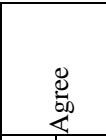 } & \multicolumn{2}{|c|}{ 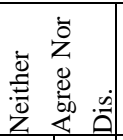 } & \multicolumn{2}{|c|}{ 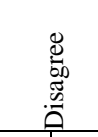 } & \multicolumn{2}{|c|}{ 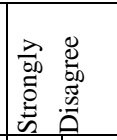 } & \multirow{2}{*}{$\sum_{\Sigma}^{\mathbb{\Xi}}$} \\
\hline & $\mathbf{N}$ & $\%$ & $\mathbf{N}$ & $\%$ & $\mathbf{N}$ & $\%$ & $\mathbf{N}$ & $\%$ & $\mathbf{N}$ & $\%$ & \\
\hline 1 We broaden our product assortment. & 59 & 30 & 83 & 42 & 15 & 7,5 & 38 & 19 & 5 & 2,5 & 3,77 \\
\hline 2 We add new products into our product range. & 64 & 32 & 79 & 40 & 21 & 11 & 30 & 15 & 6 & 3 & 3,83 \\
\hline 3 We develop new products and services. & 64 & 32 & 85 & 43 & 22 & 11 & 23 & 12 & 6 & 3 & 3,89 \\
\hline 4 We enhance the features of our products. & 56 & 28 & 87 & 44 & 14 & 7 & 34 & 17 & 9 & 4,5 & 3,74 \\
\hline 5 We make improvements in products. & 63 & 32 & 84 & 42 & 30 & 15 & 22 & 11 & 1 & 0,5 & 3,93 \\
\hline 6 We started producing the products that we have not produced before. & 41 & 21 & 67 & 34 & 30 & 15 & 41 & 21 & 21 & 11 & 3,33 \\
\hline 7 We simplify our products. & 32 & 16 & 57 & 29 & 24 & 12 & 51 & 26 & 36 & 18 & 2,99 \\
\hline 8 We standardize our products. & 36 & 18 & 79 & 40 & 30 & 15 & 41 & 21 & 14 & 7 & 3,41 \\
\hline 9 We eliminate some of our product features in order to reduce their costs. & 28 & 14 & 67 & 34 & 27 & 14 & 43 & 22 & 35 & 18 & 3,05 \\
\hline
\end{tabular}

Table V. Changes related to promotion

\begin{tabular}{|c|c|c|c|c|c|c|c|c|c|c|c|}
\hline \multirow[t]{2}{*}{ Statements } & \multicolumn{2}{|c|}{ 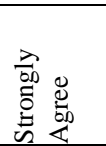 } & \multicolumn{2}{|c|}{ 总 } & \multicolumn{2}{|c|}{ 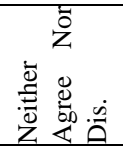 } & \multicolumn{2}{|c|}{ 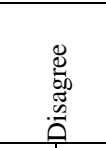 } & \multicolumn{2}{|c|}{ 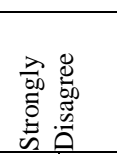 } & \multirow{2}{*}{$\underbrace{\mathbb{J}}_{\Sigma}$} \\
\hline & $\mathbf{N}$ & $\%$ & $\mathbf{N}$ & $\%$ & $\mathbf{N}$ & $\%$ & $\mathbf{N}$ & $\%$ & $\mathbf{N}$ & $\%$ & \\
\hline 1 We increase sales people's decision making authority. & 39 & 20 & 84 & 42 & 30 & 15 & 40 & 20 & 7 & 3,5 & 3,54 \\
\hline 2 We renovate the technology that our sales people use. & 39 & 20 & 75 & 38 & 33 & 17 & 45 & 23 & 8 & 4 & 3,46 \\
\hline 3 We increase public relations activities. & 48 & 24 & 82 & 41 & 31 & 16 & 25 & 13 & 10 & 5 & 3,67 \\
\hline 4 We improve our communication with customer. & 55 & 28 & 93 & 47 & 22 & 11 & 26 & 13 & 4 & 2 & 3,85 \\
\hline 5 We change our advertising tool. & 18 & 9 & 38 & 19 & 45 & 23 & 70 & 35 & 25 & 13 & 2,76 \\
\hline 6 We advertise more than before. & 28 & 14 & 58 & 29 & 30 & 15 & 57 & 29 & 25 & 13 & 3,03 \\
\hline
\end{tabular}

Table VI. Changes related to production

\begin{tabular}{|c|c|c|c|c|c|c|c|c|c|c|c|}
\hline \multirow[t]{2}{*}{ Statements } & \multicolumn{2}{|c|}{ 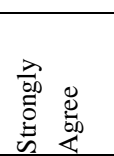 } & \multicolumn{2}{|c|}{ 苋 } & \multicolumn{2}{|c|}{ 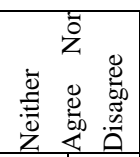 } & \multicolumn{2}{|c|}{ 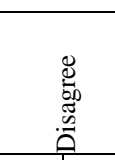 } & \multicolumn{2}{|c|}{ 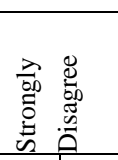 } & \multirow{2}{*}{$\begin{array}{l}\text { శ్ } \\
\sum\end{array}$} \\
\hline & $\mathbf{N}$ & $\%$ & $\mathbf{N}$ & $\%$ & $\mathbf{N}$ & $\%$ & $\mathbf{N}$ & $\%$ & $\mathbf{N}$ & $\%$ & \\
\hline 1 We renovate our production technology. & 37 & 18 & 72 & 36 & 32 & 16 & 48 & 24 & 11 & 5,5 & 3,38 \\
\hline 2 We renovate our production method. & 38 & 19 & 71 & 36 & 41 & 21 & 41 & 21 & 9 & 4,5 & 3,44 \\
\hline 3 We increase the production capacity. & 28 & 14 & 63 & 32 & 23 & 12 & 63 & 32 & 23 & 12 & 3,05 \\
\hline
\end{tabular}


Table VII. Changes related to market segmentation

\begin{tabular}{|c|c|c|c|c|c|c|c|c|c|c|c|}
\hline \multirow[t]{2}{*}{ Statements } & \multicolumn{2}{|c|}{ 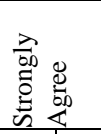 } & \multicolumn{2}{|c|}{ 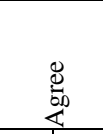 } & \multicolumn{2}{|c|}{ 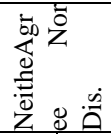 } & \multicolumn{2}{|c|}{ 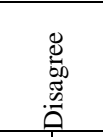 } & \multicolumn{2}{|c|}{ 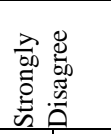 } & \multirow{2}{*}{ 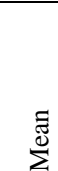 } \\
\hline & $\mathbf{N}$ & $\%$ & $\mathbf{N}$ & $\%$ & $\mathbf{N}$ & $\%$ & $\mathbf{N}$ & $\%$ & $\mathbf{N}$ & $\%$ & \\
\hline 1 We enter different market segments. & 37 & 19 & 70 & 35 & 30 & 15 & 50 & 25 & 13 & 6,5 & 3,34 \\
\hline 2 We develop the products for upscale consumers. & 44 & 22 & 69 & 35 & 34 & 17 & 41 & 21 & 12 & 6 & 3,46 \\
\hline 3 We try to reach the consumers except our current customers. & 58 & 29 & 94 & 47 & 23 & 12 & 16 & 8 & 9 & 4,5 & 3,88 \\
\hline 4 We withdraw from some markets. & 22 & 11 & 71 & 35 & 38 & 19 & 45 & 23 & 24 & 12 & 3,11 \\
\hline 5 We develop the products for downscale consumers. & 43 & 22 & 71 & 36 & 32 & 16 & 44 & 22 & 10 & 5 & 3,47 \\
\hline
\end{tabular}

Table VIII. Changes related to research \& development

\begin{tabular}{|c|c|c|c|c|c|c|c|c|c|c|c|}
\hline \multirow[t]{2}{*}{ Statements } & \multicolumn{2}{|c|}{ 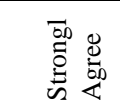 } & \multicolumn{2}{|c|}{ 芯 } & \multicolumn{2}{|c|}{ 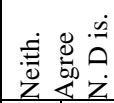 } & \multicolumn{2}{|c|}{$\dot{\mathscr{n}}$} & \multicolumn{2}{|c|}{ 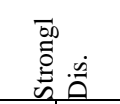 } & \multirow{2}{*}{$\sum_{\Sigma}^{\tilde{d}}$} \\
\hline & $\mathbf{N}$ & $\%$ & $\mathbf{N}$ & $\%$ & $\mathbf{N}$ & $\%$ & $\mathbf{N}$ & $\%$ & $\mathbf{N}$ & $\%$ & \\
\hline 1 We make researches as a business (enterprise). & 38 & 19 & 93 & 47 & 34 & 17 & 27 & 14 & 8 & 4 & 3,63 \\
\hline 2 We do more business with research firms. & 37 & 19 & 75 & 38 & 48 & 24 & 32 & 16 & 8 & 4 & 3,51 \\
\hline 3 We are more committed to research. & 42 & 21 & 92 & 46 & 21 & 11 & 38 & 19 & 7 & 3,5 & 3,62 \\
\hline 4 We spend more on research. & 28 & 14 & 76 & 38 & 34 & 17 & 49 & 25 & 13 & 6,5 & 3,29 \\
\hline
\end{tabular}

Table IX. T-test of overall performance

\begin{tabular}{|c|c|c|c|c|c|c|}
\hline Fac. & Overall Per. & M. of mark. act. & Std. Dev. & t-value & d.f. & Sig. \\
\hline \multirow{2}{*}{1} & Negative & 3,38 & 0,82 & \multirow{2}{*}{$-5,303$} & \multirow{2}{*}{178} & \multirow{2}{*}{0,00} \\
\hline & Positive & 4,01 & 0,75 & & & \\
\hline \multirow{2}{*}{2} & Negative & 3,02 & 0,84 & \multirow{2}{*}{$-1,093$} & \multirow{2}{*}{178} & \multirow{2}{*}{0,28} \\
\hline & Positive & 3,18 & 1,01 & & & \\
\hline \multirow{2}{*}{3} & Negative & 3,13 & 0,76 & \multirow{2}{*}{$-4,963$} & \multirow{2}{*}{178} & \multirow{2}{*}{0,00} \\
\hline & Positive & 3,79 & 0,95 & & & \\
\hline \multirow{2}{*}{4} & Negative & 3,29 & 0,85 & \multirow{2}{*}{$-2,165$} & \multirow{2}{*}{178} & \multirow{2}{*}{0,03} \\
\hline & Positive & 3,56 & 0,76 & & & \\
\hline \multirow{2}{*}{5} & Negative & 2,67 & 0,94 & \multirow{2}{*}{$-1,647$} & \multirow{2}{*}{176} & \multirow{2}{*}{0,10} \\
\hline & Positive & 2,92 & 1,01 & & & \\
\hline \multirow{2}{*}{6} & Negative & 2,86 & 0,65 & \multirow{2}{*}{$-6,317$} & \multirow{2}{*}{178} & \multirow{2}{*}{0,00} \\
\hline & Positive & 3,60 & 0,84 & & & \\
\hline \multirow{2}{*}{7} & Negative & 3,20 & 0,75 & \multirow{2}{*}{$-5,546$} & \multirow{2}{*}{178} & \multirow{2}{*}{0,00} \\
\hline & Positive & 3,83 & 0,75 & & & \\
\hline \multirow{2}{*}{8} & Negative & 3,16 & 0,89 & \multirow{2}{*}{$-1,262$} & \multirow{2}{*}{178} & \multirow{2}{*}{0,21} \\
\hline & Positive & 3,34 & 1,02 & & & \\
\hline \multirow{2}{*}{9} & Negative & 3,37 & 0,67 & \multirow{2}{*}{$-2,161$} & \multirow{2}{*}{178} & \multirow{2}{*}{0,03} \\
\hline & Positive & 3,61 & 0,73 & & & \\
\hline
\end{tabular}

Table X. T-test of revenue

\begin{tabular}{|c|c|c|c|c|c|c|}
\hline Fac. & Revenue & $\begin{array}{l}\text { Means of } \\
\text { mark.act. }\end{array}$ & $\begin{array}{l}\text { Std. } \\
\text { Dev. }\end{array}$ & t-value & d.f. & Sig. \\
\hline \multirow{2}{*}{ F1 } & Negative & 3,63 & 0,81 & \multirow{2}{*}{2,52} & \multirow{2}{*}{189} & \multirow{2}{*}{0,01} \\
\hline & Positive & 3,93 & 0,82 & & & \\
\hline \multirow{2}{*}{ F2 } & Negative & 3,32 & 0,91 & \multirow{2}{*}{$-2,84$} & \multirow{2}{*}{189} & \multirow{2}{*}{0,01} \\
\hline & Positive & 2,93 & 0,93 & & & \\
\hline \multirow{2}{*}{ F3 } & Negative & 3,45 & 0,84 & \multirow{2}{*}{0,73} & \multirow{2}{*}{189} & \multirow{2}{*}{0,47} \\
\hline & Positive & 3,55 & 1,06 & & & \\
\hline \multirow{2}{*}{ F4 } & Negative & 3,45 & 0,83 & \multirow{2}{*}{$-0,07$} & \multirow{2}{*}{189} & \multirow{2}{*}{0,95} \\
\hline & Positive & 3,45 & 0,81 & & & \\
\hline \multirow{2}{*}{ F5 } & Negative & 2,79 & 1,04 & \multirow{2}{*}{0,55} & \multirow{2}{*}{188} & \multirow{2}{*}{0,58} \\
\hline & Positive & 2,88 & 0,91 & & & \\
\hline \multirow{2}{*}{ F6 } & Negative & 3,20 & 0,89 & \multirow{2}{*}{1,79} & \multirow{2}{*}{189} & \multirow{2}{*}{0,08} \\
\hline & Positive & 3,43 & 0,78 & & & \\
\hline \multirow{2}{*}{ F7 } & Negative & 3,44 & 0,80 & \multirow{2}{*}{2,84} & \multirow{2}{*}{189} & \multirow{2}{*}{0,01} \\
\hline & Positive & 3,78 & 0,82 & & & \\
\hline \multirow{2}{*}{ F8 } & Negative & 3,43 & 0,90 & \multirow{2}{*}{$-2,99$} & \multirow{2}{*}{189} & \multirow{2}{*}{0,00} \\
\hline & Positive & 3,01 & 1,00 & & & \\
\hline \multirow{2}{*}{ F9 } & Negative & 3,48 & 0,73 & \multirow{2}{*}{0,80} & \multirow{2}{*}{189} & \multirow{2}{*}{0,42} \\
\hline & Positive & 3,57 & 0,70 & & & \\
\hline
\end{tabular}


Table XI. T-test of sales

\begin{tabular}{|c|c|c|c|c|c|c|}
\hline Fac. & Sales & $\begin{array}{l}\text { Means of } \\
\text { mark. act. }\end{array}$ & $\begin{array}{l}\text { Std. } \\
\text { Dev. }\end{array}$ & t-value & d.f. & Sig. \\
\hline \multirow{2}{*}{ F1 } & Negative & 3,86 & 0,85 & \multirow{2}{*}{1,77} & \multirow{2}{*}{180} & \multirow{2}{*}{0,08} \\
\hline & Positive & 3,65 & 0,80 & & & \\
\hline \multirow{2}{*}{ F2 } & Negative & 2,87 & 0,94 & \multirow{2}{*}{$-3,49$} & \multirow{2}{*}{180} & \multirow{2}{*}{0,00} \\
\hline & Positive & 3,34 & 0,87 & & & \\
\hline \multirow{2}{*}{ F3 } & Negative & 3,61 & 0,95 & \multirow{2}{*}{1,42} & \multirow{2}{*}{180} & \multirow{2}{*}{0,16} \\
\hline & Positive & 3,42 & 0,90 & & & \\
\hline \multirow{2}{*}{ F4 } & Negative & 3,40 & 0,87 & \multirow{2}{*}{$-0,75$} & \multirow{2}{*}{180} & \multirow{2}{*}{0,45} \\
\hline & Positive & 3,49 & 0,75 & & & \\
\hline \multirow{2}{*}{ F5 } & Negative & 2,82 & 0,88 & \multirow{2}{*}{$-0,02$} & \multirow{2}{*}{179} & \multirow{2}{*}{0,99} \\
\hline & Positive & 2,82 & 1,07 & & & \\
\hline \multirow{2}{*}{ F6 } & Negative & 3,43 & 0,79 & \multirow{2}{*}{2,16} & \multirow{2}{*}{180} & \multirow{2}{*}{0,03} \\
\hline & Positive & 3,16 & 0,89 & & & \\
\hline \multirow{2}{*}{ F7 } & Negative & 3,73 & 0,84 & \multirow{2}{*}{2,49} & \multirow{2}{*}{180} & \multirow{2}{*}{0,01} \\
\hline & Positive & 3,43 & 0,79 & & & \\
\hline \multirow{2}{*}{ F8 } & Negative & 2,95 & 0,94 & \multirow{2}{*}{$-3,76$} & \multirow{2}{*}{180} & \multirow{2}{*}{0,00} \\
\hline & Positive & 3,48 & 0,93 & & & \\
\hline \multirow{2}{*}{ F9 } & Negative & 3,56 & 0,71 & \multirow{2}{*}{0,91} & \multirow{2}{*}{180} & \multirow{2}{*}{0,36} \\
\hline & Positive & 3,46 & 0,73 & & & \\
\hline
\end{tabular}

Table XII. T-test of market share

\begin{tabular}{|c|c|c|c|c|c|c|}
\hline Fac. & $\begin{array}{l}\text { Market } \\
\text { share }\end{array}$ & $\begin{array}{l}\text { Means of } \\
\text { mark.act. }\end{array}$ & $\begin{array}{l}\text { Std. } \\
\text { Dev. }\end{array}$ & $t$-value & d.f. & Sig. \\
\hline \multirow{2}{*}{ F1 } & Negative & 3,89 & 0,73 & \multirow{2}{*}{3,31} & \multirow{2}{*}{149} & \multirow{2}{*}{0,00} \\
\hline & \begin{tabular}{|l|} 
Positive \\
\end{tabular} & 3,46 & 0,84 & & & \\
\hline \multirow[b]{2}{*}{ F2 } & \begin{tabular}{|l|} 
Negative \\
\end{tabular} & 3,05 & 0,96 & \multirow{2}{*}{$-1,37$} & \multirow[b]{2}{*}{149} & \multirow{2}{*}{0,17} \\
\hline & Positive & 3,27 & 0,97 & & & \\
\hline \multirow{2}{*}{ F3 } & Negative & 3,57 & 0,91 & \multirow{2}{*}{0,87} & \multirow{2}{*}{149} & \multirow{2}{*}{0,39} \\
\hline & \begin{tabular}{|l|} 
Positive \\
\end{tabular} & 3,44 & 0,98 & & & \\
\hline \multirow{2}{*}{ F4 } & Negative & 3,49 & 0,89 & \multirow{2}{*}{$-0,26$} & \multirow{2}{*}{149} & \multirow{2}{*}{0,79} \\
\hline & Positive & 3,53 & 0,75 & & & \\
\hline \multirow{2}{*}{ F5 } & Negative & 2,87 & 0,94 & \multirow{2}{*}{$-0,21$} & \multirow{2}{*}{148} & \multirow{2}{*}{0,84} \\
\hline & \begin{tabular}{|l|} 
Positive \\
\end{tabular} & 2,91 & 1,13 & & & \\
\hline \multirow{2}{*}{ F6 } & Negative & 3,41 & 0,80 & \multirow{2}{*}{2,61} & \multirow{2}{*}{149} & \multirow{2}{*}{0,01} \\
\hline & Positive & 3,05 & 0,83 & & & \\
\hline \multirow{2}{*}{ F7 } & Negative & 3,62 & 0,79 & \multirow{2}{*}{0,89} & \multirow{2}{*}{149} & \multirow{2}{*}{0,38} \\
\hline & Positive & 3,49 & 0,89 & & & \\
\hline \multirow{2}{*}{ F8 } & Negative & 3,14 & 0,96 & \multirow{2}{*}{$-1,35$} & \multirow{2}{*}{149} & \multirow{2}{*}{0,18} \\
\hline & Positive & 3,37 & 1,02 & & & \\
\hline \multirow{2}{*}{ F9 } & Negative & 3,53 & 0,74 & \multirow{2}{*}{$-0,35$} & \multirow{2}{*}{149} & \multirow{2}{*}{0,73} \\
\hline & Positive & 3,57 & 0,71 & & & \\
\hline
\end{tabular}

